\title{
Performance of some potato accessions of USA and Bangladesh in relation to dry matter yield and biochemical constituent
}

\author{
M. A. Mahamud*, M. A. H. Chowdhury, M. A. Rahim ${ }^{1}$ and P. R. Sheel \\ Department of Agricultural Chemistry, ${ }^{1}$ Department of Horticulture, BAU, Mymensingh-2202, Bangladesh \\ *Email: mdasifbau@gmail.com
}

\begin{abstract}
Present research was designed to evaluate the dry matter yield and biochemical constituents of twenty two potato accession of USA in comparison with two Bangladeshi varieties. Studied biochemical constituents were starch, protein and vitamin C contents. Analyses were performed from November 2014 to April 2015 in different laboratories of Bangladesh Agricultural University, Mymensingh. Potato accessions differed significantly with respect to dry matter content and biochemical parameters. Dry mater content was found highest in accession AC 10110. Considering biochemical constituent, the accession AC 10062 showed highest protein and vitamin $\mathrm{C}$ contents. On the other hand, accession AC 10081 had the highest starch content. Significant positive correlation was observed between dry matter and starch content while significant negative correlation was observed between starch and protein contents. Considering both dry matter yield and biochemical parameters AC 10081 was found as the best USA potato accession for cultivation in Bangladesh.
\end{abstract}

Keywords: Potato accession, Dry matter, Biochemical constituent

\section{Introduction}

Potato is one of the important food crops in the world. It is popularly known as 'The king of vegetables', the fourth most important food crop in the world after rice, wheat and maize. It is a member of the family solanaceae and belongs to the genus Solanum. Its diversity is vast with approximately 5000 varieties of potato are known and most cultivated varieties belong to the species (Solanum tuberosum L.) (Ganga, 2011). Potato is very nutritious tuber vegetable and rich source of starch, vitamin $C$ and $B$ and minerals. It contains about $20.6 \%$ carbohydrates, $2.1 \%$ protein, $0.3 \%$ fat, $1.1 \%$ crude fiber and $0.9 \%$ ash. It also contains a good amount of essential amino acids like leucine, tryptopan and isoleucine (Khurana and Naik, 2003). Potato also contains a variety of phytonutrients that have antioxidant activity. Among these, some important health-promoting compounds are carotenoids, flavonoids, caffeic acid and tuber storage proteins (such as patatin) which exhibit activity against free radicals (Breithaupt and Bamedi, 2002).

Potato is a frequent item in the human diet; it is used in a variety of ways. Freshly harvested tuber contains about $80 \%$ water and $20 \%$ dry matter. About 60 to $80 \%$ of the dry matter is starch. On a dry weight basis, the protein content of potato is similar to that of cereals but protein content in potato is very high in comparison with other roots and tubers. Potato protein is quality protein because of essential and valuable amino acid present in tubers. In addition, the potato is low in fat and rich in several micronutrients (Lutaladio and Castaldi, 2009). Most of the potato varieties now grown in Bangladesh have the white flesh. Colored potato is now growing elsewhere in the world for its antioxidant rich character. In 2007, a number of colored potato varieties has been introduced from University of Wisconsin, Madison, USA and finally in Germplasm Center of Bangladesh Agricultural University. Their yield potential is very high considering climatic condition of Bangladesh. Nutritional status of those accessions is yet to be studied in Bangladesh. Considering all these points, the present work has been undertaken in order to characterize the inherent colored potato accessions in relation to dry mater yield and biochemical constituent (starch, protein and vitamin $\mathrm{C}$ ) with a view to investigating the relationship among the accessions and selecting suitable ones for commercial cultivation under Bangladesh condition. 


\section{Materials and Methods}

To determine the dry matter yield and biochemical constituent twenty two potato accessions of USA and two varieties from Bangladesh were used as experimental materials. Potato accessions from USA were AC 10016, AC 10062, AC 10063, AC 10064, AC 10068, AC 10069, AC 10072, AC 10073, AC 10074, AC 10076, AC 10077, AC 10078, AC 10081, AC 10097, AC 10109, AC 10110, AC 10112, AC 10120, AC 10122, AC 10123, AC 10125 and AC 10190, where thereof two varieties Diamant and Cardinal from Bangladesh. Sample potato tubers were collected from Horticulture Farm, Bangladesh Agricultural University, Mymensingh. Six uniformly shaped, disease free, healthy potato tuber of each accessions were collected from three replicated plots. Immediately after collection, each sample were kept in a labeled, air tight plastic zipper bag and stored at $4-6^{\circ} \mathrm{C}$ temperature with $65-80 \%$ relative humidity. The chemical analysis was conducted in the laboratories of Department of Agricultural Chemistry, Biochemistry and Molecular Biology, and Professor Muhammed Hussain Central Laboratory, Bangladesh Agricultural University Mymensingh.

Tuber dry matter content was determined after oven drying the potato tuber at $80^{\circ} \mathrm{C}$ for 72 hours until constant weight attained. Starch content of the potato tubers were determined by Fehling's method as outlined by Jacskon (1973) and McCardy et al. (1950) with the use of alkaline solution. Total N was analyzed using Kjeldahl method and used for the calculation of the crude protein concentration by multiplying with a conversion factor of 5.85 . Vitamin $\mathrm{C}$ was determined by the indophenol dye extraction method (Ranganna, 1994). This procedure was based upon the quantitative discoloration of 2, 6dichlorophenol indophenol by ascorbic acid. Data were analyzed for ANOVA with the help of a computer package program of MSTAT (Mathematical and Statistical calculation). A one way ANOVA was made by $\mathrm{F}$ variance test. The pair comparisons were performed by DMRT test at $5 \%$ level of probability (Gomez and Gomez, 1984).

\section{Results and Discussion}

\section{Dry matter content}

The results showed that the dry matter content varied within the range of $12.20-24.57 \%$ (Fig. 1). The highest dry matter content (24.57\%) was produced by the accession AC 10112 which was statistically identical with the accession AC 10068, AC 10073, AC 10081 and AC 10190. Their dry matter contents were higher than the promising variety Cardinal $(15.20 \%)$ and Diamant $(16.10 \%)$. This might be due to easy and early sprouting which in return helped the plant to attain maximum dry matter content (Kabir, 2014). On the other hand, the lowest dry matter content was found in the accession AC 10062 which was statistically identical with the accession AC 10110 and AC 10125. Singh et al. (2009) and Kita (2002) also noted genetic variation for dry matter in different potato varieties and the values falls within the range of this study. The difference in dry matter content among the cultivars could be due to variation in hereditary factors, agro-climatic conditions as well as agronomic practices followed for raising the crop (Singh and Ezekiel, 2008; Sood et al., 2008; Talburt and Smith, 1975; Lisinska and Leszczynski, 1989; Abong et al., 2010; Kumar et al., 2003). 


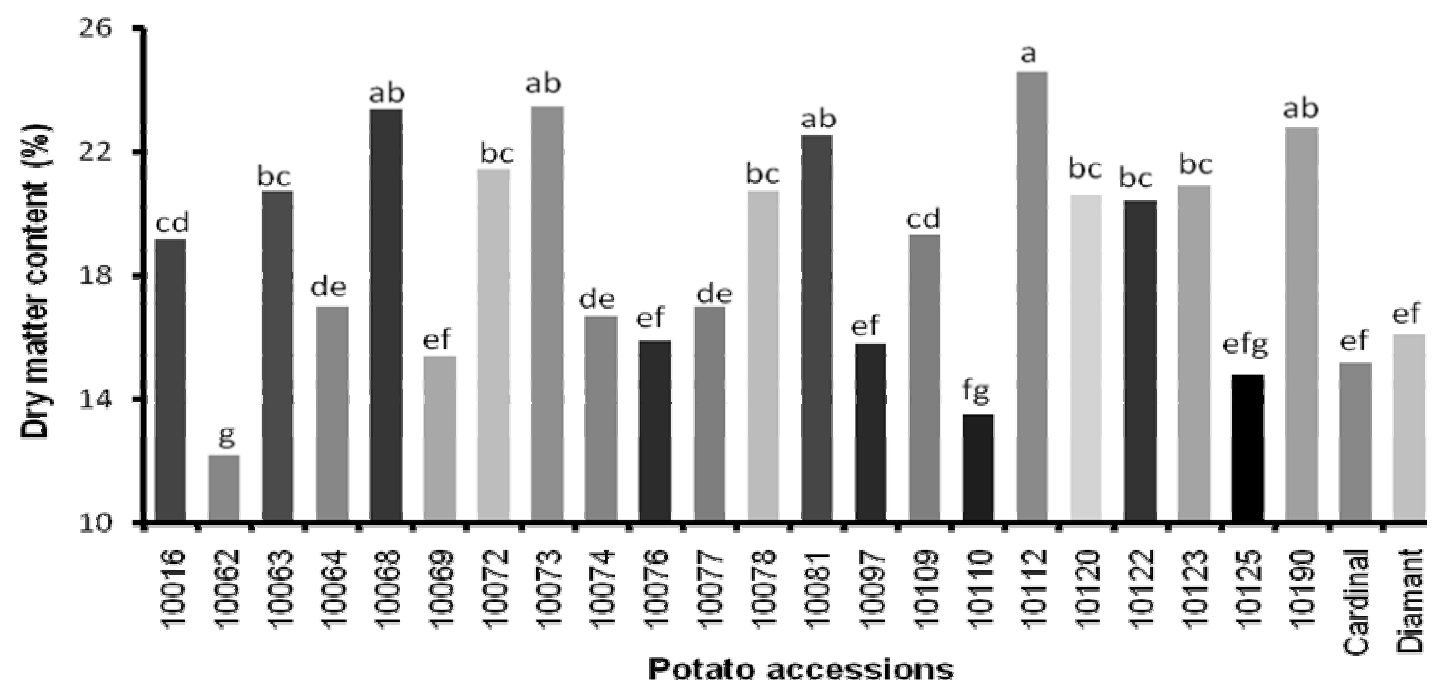

Fig. 1. Dry matter content of some potato accessions of USA and Bangladesh

\section{Biochemical constituents}

Biochemical compositions of potato tubers differed significantly among the accessions. To a large extent, it depends on genetic factors, although tubers of the same potato variety, even of the same plant can vary depending on chemical constituents. It is also affected by the age and maturity of potato tubers as well as environmental conditions and changes during storage. Among the biochemical constituents, we considered only the starch, protein and vitamin $\mathrm{C}$ contents in this study.

\section{Starch content}

Starch contents in potatoes were shown in Table 1. Starch is the major constituent of potato tubers and it ranged between 55.50 to $77.50 \%$ of dry weight (DW), with the highest content in the accession AC 10081 which was statistically identical with the accession AC 10190 (75.23\% DW). The lowest amount of starch was found in the accession AC 10062 which was followed by accession AC $10069(56.10 \%$ DW) and AC $10110(56.37 \%$ DW $)$, respectively. Considering the Bangladeshi varieties, Diamant $(63.57 \% \mathrm{DW})$ had significantly higher amount of starch content over Cardinal $(59.73 \% \mathrm{DW})$. The values fall within the range reported by Sood et al. (2008). Ramezani and Aminleri (2004) reported that starch content of four exotic potato cultivars ranging from 55.3 to $60.6 \%$ DW which are contrast to the values of present study. The difference in starch content among the cultivars may be due to the differences in morphology of tubers as well as internal distribution of nutrients (Kroner and Volksen, 1950; Talburt and Smith, 1975), and their differential root absorption pattern and translocation to aerial parts, finally distribution to potato tubers for their various metabolic activities (Sood et al., 2008).

\section{Protein content}

The perusal of the results inferred that the protein content varied significantly in different potato varieties (Table 1). The protein content varied from $5.19-12.79 \%$ of dry weight (DW). The results showed that maximum protein was biosynthesized in the potato accession AC 10062 (12.79 DW which was identical to the accession AC 10069 (12.44\% DW). The lowest protein content (5.19\% DW) was observed in the accession AC 10122. These values are in general agreement with those reported in the literature (Tekaling and Hammes, 2005; Kolbe and Stephan- Beckmann, 1997). In contrary, little higher range of protein contents 9.88 to $11.86 \%$ DW was reported by Abbasi et al. (2011). The variations in the proximate composition might be due to genetic and non-genetic factors. 
Table 1. Starch, protein and vitamin C contents of some potato accessions of USA and Bangladesh

\begin{tabular}{|c|c|c|c|c|}
\hline SI. no. & Accession & $\begin{array}{l}\text { Starch } \\
(\% \text { DW) }\end{array}$ & $\begin{array}{l}\text { Protein } \\
\text { (\% DW) }\end{array}$ & $\begin{array}{c}\text { Vitamin C } \\
\left(\mathrm{mg} 100 \mathrm{~g}^{-1} \mathrm{FW}\right)\end{array}$ \\
\hline 1 & 10016 & $67.77 \mathrm{~d}-\mathrm{g}$ & $9.21 \mathrm{fgh}$ & $18.49 \mathrm{efg}$ \\
\hline 2 & 10062 & 55.501 & $12.79 \mathrm{a}$ & $27.02 \mathrm{a}$ \\
\hline 3 & 10063 & $58.43 \mathrm{kl}$ & $10.10 \mathrm{de}$ & 19.58 cde \\
\hline 4 & 10064 & $64.43 \mathrm{ghi}$ & $10.63 \mathrm{~cd}$ & $19.27 \mathrm{de}$ \\
\hline 5 & 10068 & 73.23 bc & $6.08 \mathrm{~m}$ & $16.02 \mathrm{jk}$ \\
\hline 6 & 10069 & $56.10 \mathrm{kl}$ & $12.44 \mathrm{a}$ & $26.57 \mathrm{a}$ \\
\hline 7 & 10072 & $71.40 \mathrm{~cd}$ & $6.12 \mathrm{~m}$ & $14.40 \mathrm{Im}$ \\
\hline 8 & 10073 & $73.00 \mathrm{bc}$ & 6.961 & $15.15 \mathrm{kl}$ \\
\hline 9 & 10074 & $66.90 \mathrm{e}-\mathrm{h}$ & $8.99 \mathrm{gh}$ & $18.08 \mathrm{eh}$ \\
\hline 10 & 10076 & $59.93 \mathrm{jk}$ & 9.81 efg & $17.61 \mathrm{fj}$ \\
\hline 11 & 10077 & $62.43 \mathrm{ij}$ & 9.65 efg & $16.88 \mathrm{gj}$ \\
\hline 12 & 10078 & $70.23 \mathrm{cde}$ & $7.66 \mathrm{jkl}$ & $11.82 \mathrm{n}$ \\
\hline 13 & 10081 & $77.50 \mathrm{a}$ & $8.05 \mathrm{ij}$ & 19.10 def \\
\hline 14 & 10097 & 66.67 e-h & $8.48 \mathrm{hi}$ & $16.60 \mathrm{hk}$ \\
\hline 15 & 10109 & $64.67 \mathrm{f}-\mathrm{i}$ & $5.87 \mathrm{mn}$ & $18.33 \mathrm{efg}$ \\
\hline 16 & 10110 & $56.37 \mathrm{kl}$ & $11.56 \mathrm{~b}$ & $24.29 \mathrm{~b}$ \\
\hline 17 & 10112 & 70.37 cde & $7.10 \mathrm{kl}$ & $13.03 \mathrm{mn}$ \\
\hline 18 & 10120 & $66.93 \mathrm{e}-\mathrm{h}$ & $7.82 \mathrm{ijk}$ & $17.53 \mathrm{f}-\mathrm{j}$ \\
\hline 19 & 10122 & $68.37 \mathrm{def}$ & $5.19 n$ & $16.37 \mathrm{ijk}$ \\
\hline 20 & 10123 & $69.50 \mathrm{cde}$ & 7.35 jkl & $17.67 \mathrm{f}-\mathrm{i}$ \\
\hline 21 & 10125 & $57.70 \mathrm{kl}$ & $11.12 \mathrm{bc}$ & $21.01 \mathrm{c}$ \\
\hline 22 & 10190 & $75.23 a b$ & $9.69 \mathrm{efg}$ & $17.55 \mathrm{f}-\mathrm{i}$ \\
\hline 23 & Cardinal & $59.73 \mathrm{jk}$ & $11.17 \mathrm{bc}$ & $23.12 b$ \\
\hline 24 & Diamant & $63.57 \mathrm{hi}$ & 9.97 def & $20.10 \mathrm{~cd}$ \\
\hline $\mathrm{LSD}_{0.05}$ & & 3.40 & 0.75 & 1.39 \\
\hline $\mathrm{CV}(\%)$ & & 3.16 & 5.13 & 4.59 \\
\hline $\mathrm{SE}( \pm)$ & & 1.29 & 0.43 & 0.77 \\
\hline
\end{tabular}

DW $=$ Dry weight, $\mathrm{FW}=$ Fresh weight

\section{Vitamin C content}

Vitamin $C$ content of the tested potato accession lies between 11.82 to $27.02 \mathrm{mg} 100 \mathrm{~g}^{-1}$ fresh weight (FW) with the highest value in accession AC 10062 and the lowest in AC 10078. Love et al. (2004) examined tuber vitamin $C$ content in 75 genotypes and found concentrations ranging from 11.5 to 29.8 $\mathrm{mg} 100 \mathrm{~g}^{-1} \mathrm{FW}$. A British study measuring vitamin C in 33 cultivars grown in three locations around Europe (Dale et al., 2003). If these author's results in dry weight are converted to fresh weight assuming potatoes having $80 \%$ water, a range of 13 to $30.8 \mathrm{mg}$ vitamin C per $100 \mathrm{~g} \mathrm{FW}$ will be obtained, which is consistent of our result and with the report of Love et al. (2004). The variation of vitamin C content in different accessions may be due to the effect of genotype, and the accession AC 10062 might have greater adaptability to the climatic condition of the experimental site.

\section{Correlation among biochemical parameters}

Dry matter content of potato tubers had direct significant correlation with starch content at $1 \%$ level of probability which is supported by the result of Yagbani et al. (2006). The correlation coefficient was $0.84^{* *}$ and the regression line was $y=1.542 x+36.75$ (Fig. 2A). Considering starch and protein content significant negative correlation $\left(r=-0.74^{* *}\right)$ was observed with regression line $y=-0.249 x+25.26$ (Fig. 2B). Negative correlation between protein and starch contents was also found by Burešová et al. (2010). 

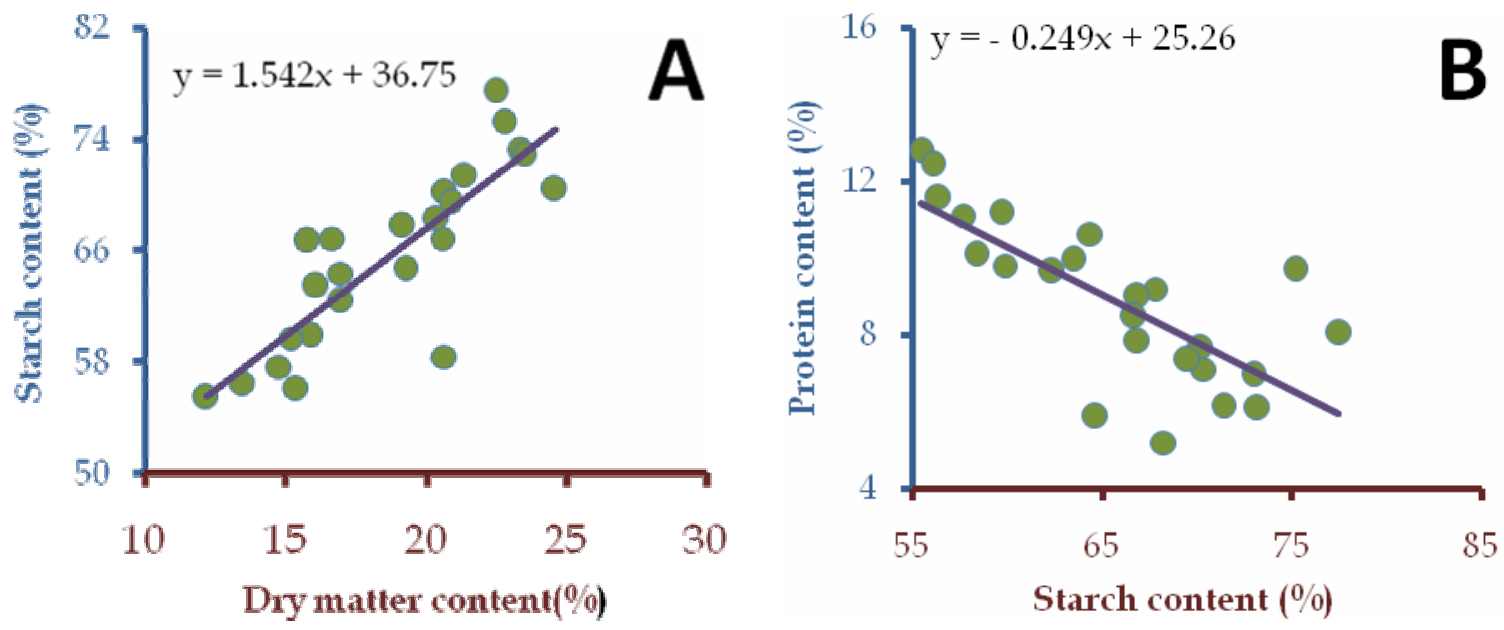

Fig.2. Correlation between dry matter and starch content (A), starch and protein content (B) of different potato accessions of USA and Bangladesh

\section{Conclusion}

Both USA potato accessions and Bangladeshi potato varieties showed variability in relation to dry matter yield and biochemical constituents. Among USA accessions, AC 10112 produced the highest dry matter yield. On the other hand the highest starch content was found in AC 10081 though highest protein and vitamin $C$ were biosynthesized by the accession AC 10062. Among the Bangladeshi varieties, neither Diamant nor Cardinal could compete with the best USA accessions (AC 10112, AC 10081and AC 10062) in relation to dry matter yield, starch, protein and vitamin $\mathrm{C}$ contents.

\section{Acknowledgement}

We thank Ministry of Science and Technology, Government of the People's Republic of Bangladesh for providing financial support. We also thank Department of Agricultural Chemistry and Horticulture, BAU for technical support and providing the potato germplasom.

\section{References}

Abbasi, K.S., Masud, T., Gulfraz, M. and Ali I.M. 2011. Physico-chemical, functional and processing attributes of some potato varieties grown in Pakistan. African J. Biotech. 10(84): 19570-19579.

Abong, G.O., Okoth, M.W., Imungi, J.K. and Kabir, J.N. 2010. Evaluation of selected Kenya potato cultivars for processing into potato crisps. Agric. Biol. J. North. America, 1(5): 886-893.

Breithaupt, D.E. and Bamedi, A. 2002. Carotenoids and carotenoid esters in potatoes (Solanum tuberosum L.): New insights into an ancient vegetable. J. Agric. Food Chem., 50(24): 7175-7181.

Burešová, I., Sedláčková, I., Faměra, O and Lipavský, J. 2010. Effect of growing conditions on starch and protein content in triticale grain and amylose content in starch. Plant Soil Environ., 56 (3) 99-104.

Dale, M.F.B., Griffiths, D.W. and Todd, D.T. 2003. Effects of genotype, environment, and postharvest storage on the total ascorbate content of potato (Solanum tuberosum) tubers. J. Agric. Food Chem., 51: 244-248.

Ganga. H. 2011. Screening of potato varieties for chemical composition and processing, master of home science, department of food science and Nutrition College of rural home science, Dharwad university of agricultural sciences, Dharwad.

Gomez, A.K. and Gomez, A.A. 1984. Statistical Procedures for Agricultural Research. IRRI, Los Banos, Philippines. p. 207-215.

Jackson, M.L. 1973. Soil Chemical Analysis. p. 41-196. Prentice Hall of India Rt. Ltd. New Delhi, India.

Kabir, H. 2014. Effect of seed tuber size on the growth and yield of twenty three accessions of potato, MS thesis, Department of Horticulture, Bangladesh Agricultural University, Mymensingh.

Kita, A. 2002. The influence of potato chemical composition on crisp texture. Food Chem., 76: 173-179. 
Khurana, P.S.M. and Naik, P.S. 2003. The Potato: an overview. In the Potato Production and Utilization in Sub- tropics. p. 1-14. Mehta Publication, New Delhi, India.

Kolbe, H. and Stefan-Beckmann, S. 1997. Development, growth and chemical composition of the potato crop (Solanum tuberosum L.). II. Tuber and whole plant. Potato Research, 40: 135-153.

Kumar, D., Ezekiel, R. and Khurana, S.M.P. 2003. Effect of location, seasons and cultivar on the processing quality of potatoes. J. Indian Potato Assoc., 30 (3-4): 247-251.

Kroner, W. and Volksen, W. 1950. The Potato. p.6-18. Johann Ambrosius Barth, Leipzig.

Lisinska, G. and Leszczynski, W. 1989. Potato science and technology. p. 11-202. Elsevier Science Publishers Ltd., New York, America.

Love, S.L.S., Shafii, T., Price, B.W.J., Mosley, A.R. and Thornton, R.E. 2004. Stability of expression and concentration of ascorbic acid in North American potato germplasm. Hort. Sci. 39: 156-160.

Lutaladio, N.B., Castaldi, L. 2009. Potato: The hidden treasure. J. Food Comp. Anal., 22: 491-493.

McCardy, R.M., Goggalz, J., Siviera, V. and Owens, H.S. 1950. Dtermination of starch and amylase in vegetables. J. Anal. Chem., 20: 1157-1158.

Ramezani, R. and Aminlari, M. 2004. Comparing chemical composition of four potato varieties for processing. J. Food Sci. and Technol., 41(6): 680-691.

Ranganna, S. 1994. Handbook of Analysis of Quality Control for Fruit and Vegetables Products. 2nd Ed. p. 10-674. TATA McGrawHill Publishing Co. Ltd. New Delhi..

Singh, S.V., Marwaha, R.S., Kumar, D., Kumar, P. and Pandey, S.K. 2009. Suitability of potato varieties grown in north-eastern Indian plains for processing. Potato J., 36 (1-2): 25-34.

Singh, B. and Ezekiel, R. 2008. Reducing sugar content and chipping quality of tubers of potato cultivars after storage and reconditioning. Potato J., 35 (1-2): 23-30.

Sood, D.R., Kalim, S., and Shilpa 2008. Biochemical evaluation of potato tubers and peels. Indian J. Nutr. Dietet., 45: 410-420.

Talburt, M.S.W.F. and Smith, O. 1975. Potato Processing. The AVI Publishing Company, Inc., United States of America, p. 67-106, 305-363.

Tekalign, T. and Hammes, P.S. 2005. Growth and productivity of potato as influenced by cultivar and reproductive growth. II. Growth analysis, tuber yield and quality. Sci. Hort., 105: 29-44.

Yaghbani, M, Mohammadzadeh, J, and Najafi, M. 2006: Composition and characterization of starch extraction from various potato cultivars in Golestan province of Iran. J. Food Sci. and Technol., 43 (6) 667-670. 